\title{
JATIO SANGSAD BHABAN OR NATIONAL ASSEMBLY BUILDING AND SUSTAINABILITY
}

\author{
Bayezid Ismail Choudhury \\ Department of Architecture, Khulna University of Engineering \& Technology, Khulna -9203, Bangladesh
}

Received: 01 November 2020

Accepted: 08 December 2020

\begin{abstract}
Designed by American architect, Louis I. Kahn, the Jatio Sangsad Bhaban (JSB) or National Assembly Building of Bangladesh is a world-renowned iconic building situated in Bangladesh. Louis I. Khan was commissioned to design the JSB during the period before the term 'sustainable' was coined. In sustainable term it has controversial standing due to its cost, social and participatory aspects. However, it still stands as one of the masterpieces that represent hope and aspiration of the people of Bangladesh. This paper intends to look at the JSB through the lens of 'sustainability' to ascertain the degree of sustainability it has or has not achieved considering three tenets of sustainability, namely environmental, social and economic.
\end{abstract}

Keywords: Jatio Sangsad Bhaban; Louis I Kahn; Sustainability.

\section{INTRODUCTION}

The JSB, or National Assembly Building of Bangladesh, is regarded as one of the significant buildings in the history of world architecture. It was designed by American architect, Louis I. Kahn, who was appointed in 1962 (Choudhury \& Armstrong, 2012). The JSB was commissioned by military dictator, Ayub Khan, who's prime motive was political, far from patronising iconic architecture. Ayub Khan's intention was to please the people of East Pakistan (presently Bangladesh) who were unhappy due to political and economic suppression by West Pakistan (Choudhury \& Bell, 2011). The JSB can also be perceived as a product of geopolitics during the cold war era (Choudhury \& Armstrong, 2013). Thus, its very birth can be perceived as more political, rather than architectural. However, the JSB stands as an architectural marvel, a testimony to the grand architecture of the $20^{\text {th }}$ century. The JSB is not only regarded as an architectural masterpiece but also represents the national identity of Bangladesh (Choudhury \& Armstrong, 2012).

Despite its position as an architectural icon, until now it has not been scrutinised and examined from the standpoint of sustainability. Sustainability in architecture is no longer a buzzword, as it encompasses all three important aspects of human life, i.e., ecology, economy and society. Today great architects, designers and other professionals related to the building industry make an all-out effort to integrate sustainability issues into the Whole Life Cycle (WLC), from the inception, design development and dismantling phases of a building (Akadiri et al., 2012). Looking at the JSB in terms of sustainable issues will produce a renewed understanding that will add value and meaning to the existing norms of the JSB. Understanding the JSB from the perspective of sustainability will also generate new thoughts regarding iconic buildings which might have incorporated sustainability issues that would elevate its standing from the existing.

The three sustainability elements in architecture, environmental, social and economic, are widely accepted criteria in recent architectural trends (Akadiri et al., 2012). Contemporary, leading architects, following this trend, are articulating their architecture in the context of sustainability (Butera, 2005). Since 2000 there has been a trend for iconic architecture to attach its meaning to sustainability (Aatty and Slik, 2019). As such, it is also important to analyse and synthesise great architectural works from the past, like the JSB, in the light of sustainability.

\section{SUSTAINABILITY AND SUSTAINABLE ARCHITECTURE}

The term 'sustainability' has deep roots, going back to 1917 when a German forester, Hans Carl von Carlowitz, outlined a system for managing forests. Later, the issue re-emerged in the early seventies when the need for conservation of oil came to light, especially in the USA. In the 1980s, it achieved further importance as 'green' design, and then as ecological design in the late eighties (Scoones, 2007). In 1987 a report formulated by a commission chaired by Gro Brundtland clearly defined sustainability as:

"Sustainable development is development that meets the needs of the present without compromising the ability of future generations to meet their own needs" (WCED 1987 a: 43).

Sustainable development in relation to architecture was presented for the first time in Gavle in 1998 and published in agenda 21 in the document called sustainable buildings (Dokumenty, 1992). Today architecture is an inseparable part of the ecology and society for its sheer size. It is the largest consumer of material resources, 
energy and water. Due to its all-encompassing impact on nature, it emerges as a major cause of concern in the environment. For a building's overall presence in human habitat, policymakers and thinkers unanimously agree on the need to relate building issues with the concept of sustainability. Nowadays, scholars are formulating appropriate strategies to minimise the adverse impact of the building industry in our life. With the proper policy, a sustainable building can make a significant contribution to overall sustainable development (Akadiri et al., 2012).

To engage with the complex concept of sustainable architecture, one must seek multidisciplinary teamwork (Stasinopoulos, 2005). In sustainable architecture the role of the architect is more than as a creator; rather, they work to coordinate different professionals, including contractors, energy specialists, managers, economists and environmentalists. In order to achieve a sustainable architecture, the architect has to thrive in an interdisciplinary process (Kamionka, 2011).

Since the concept of architecture sustainability was introduced, the three tenets of sustainable architecture, environmental, social and economic, have been inseparable parts of any great building (Akadiri et al., 2012). In regard to the sustainability of architecture, Halliday refers to the environment, less pollution and less degradation of the environment due to the project, social, supporting communities and involving stakeholders in the decision making, and economy, good project management (2008). Kamionka argues the environmental aspect, as there is less impact on nature, social sustainability is achieved by improving and enhancing the quality of life and participatory practices and economy relate to the profitability of project (2011).

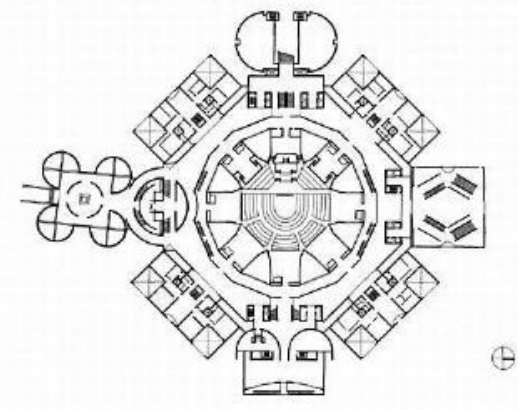

Figure 1: Plan of National Assembly Block

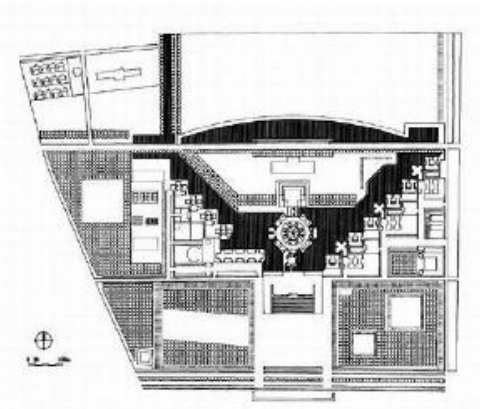

Figure 2: Master plan of JSB

\section{JSB AND ENVIRONMENTAL SUSTAINABILITY}

Since Louis Kahn and his firm started working on the JSB before the environmental sustainability movement came into being, no trace of an environmental aspect of the JSB is found in the existing literature of the JSB. However, some aspects of Louis Kahn's design, which are linked to environmental sustainability issues, can be discussed here.

The assembly block of the JSB is geometrically a square which is skewed facing north and south making the frontal side broader. Other subsidiary structures are also facing south. Facing all of the structure towards the south is an environmentally sensitive approach in the Bangladesh context. Although the JSB is heavily dependent on mechanical cooling, a measure to achieve passive cooling has been achieved using a double wall with punches on the east and west side which reduce direct solar heat radiation. This measure is especially appropriate for tropical conditions like Bangladesh.

In terms of Indoor Environmental Quality (IEQ), the JSB is well designed. The JSB provides adequate acoustical, thermal and visual comfort for all. As it is surrounded by open space without vehicular traffic and nearby crowds, it can avoid any distracting noise sources. With its double wall and indirect roof lighting in the central assembly space, it has been able to avoid glare within its space and provide users with soothing lighting. Although it has a fort-like appearance, in some places it is visually connected with the outdoor space. Moreover, in some places, it uses operable windows which provide users with some degree of control over the temperature and ventilation.

The design of the JSB is environmentally sustainable as it respects its natural contour. According to Celebi (2003), a large intervention into natural features and contours is detrimental to an existing site. While designing the JSB, the project did not go for any radical transformation that would disturb the natural contour. It did not make any disturbance by interfering to the existing water table that would have resulted in contamination. Only a large water body was made, which adds value to the natural setting without disturbing the ecology. In urban design sustainability terms, it is quite successful as it integrates transportation on its periphery with the grand Manik Mia 
Avenue on the south. According to Celebi (2003), public transportation must be integrated carefully to achieve sustainable practice in urban design.

On the contrary, when JSB was built, it was located on the outskirts of the city, in an agricultural farm with lots of plantation and vegetation. It did not take into consideration the need for retaining existing flora and fauna. However, few plantations were done while addressing the landscape in the design phase. The concept of preserving flora and fauna was not considered at that time, perhaps because it was not considered a very pressing issue due to abundance in the vicinity. In sustainable architecture, there are four types of conservation, i.e., energy, water, material and land conservation (Akadiri et al., 2012). These aspects were not comprehensively addressed during the construction of the JSB. However, employing some measure and mechanism, some sustainable issues can be obtained at present.

Energy Conservation: According to Lenzen and Treloar (2002), the energy used in the Whole Life Cycle (WLC) of a building contributes significantly to the creation of greenhouse gas (GHG) emissions. In the case of the JSB, during the early construction period it was not possible to implement energy conservation measures, due to lack of foresight. However, at present we can reduce energy conservation by properly addressing operational energy. Thormark (2006), opined that $85-90 \%$ of total energy consumption comes from operational energy consumption generated from electricity, gas and the burning of oil or coal. By using high-efficiency heating, cooling, and ventilation systems and smaller HVAC systems we can considerably reduce the JSB's energy consumption. Replacing the JSB's old HVAC system with efficient, low energy HVAC systems may appear expensive now, but in the long run will reduce overall costs. If we can properly address the issue of operational costs related to the JSB, we can turn it into an energy sustainable building. By reducing the use of fossil fuel and promoting consumption of renewable energy, we can achieve the goal of sustainability for the JSB.

Material Conservation: We can evaluate very little in term of material conservation for the JSB as most use was confined to the period of construction. This includes reducing and recovering construction waste, reuse and recycling material, the storage and disposal of construction waste, specifically natural and local material, specifically non-toxic or less toxic material, etc. (Akadiri et al., 2012).

Water Conservation: Fresh water is a scarce material and essential for our very existence. It is also an important element in the building industry. Water is used in every phase of the building life cycle. Water is used during the construction of building materials, the actual on-site construction process and after the building is commissioned (Akadiri et al., 2012).

In the case of the JSB, water use for the operational processes is important as its previous process (construction) cannot be taken into consideration. By using the following measures, its operational cost can be reduced:

a. By applying plumbing measures, such as ultra-low-flow toilets and urinals, sensored and low flow sinks, etc.

b. By employing rainwater harvesting methods and recycling gray water for toilet flushing.

c. By using local and indigenous plants in the landscape, which require less water.

d. By Xeriscaping.

e. By reducing water pressure, we can lessen the wastage of water.

f. By employing vacuum-assisted and bio-composting toilets.

\section{JSB AND SOCIAL SUSTAINABILITY}

“... Social sustainability combines design of the physical realm with design of the social world - infrastructure to support social and cultural life, social amenities, systems for citizen engagement and space for people and places to evolve" (Woodcraft et al., 2012).

Social sustainability in architecture has several components. The first is social structure, which includes the aspect of well-maintained public gathering space (Woodcraft et al., 2012). The JSB, or National Assembly Building, is a well-maintained place of congregation for public representatives. Unfortunately, the general public is not permitted at most times of the year into the JSB premises. The second is social and cultural life, which include a thriving community life and festivals (Woodcraft et al., 2012). Only selected representatives are allowed into the JSB premises when any festivals take place. The vast 610 acres of land remain out of bound for the general mass, contradicting the JSB's very notion of democratic space. The third aspect of social sustainability in architecture is voice and influence, which refers to participatory decision making (Woodcraft et al., 2012). Records show that when Kahn designed this building he consulted with top architects and decision makers. The bottom-up approach, or participation of the mass of the people, was missing in the design phase. The fourth aspect is space to grow, which refers to community-driven stewardship (Woodcraft et al., 2012). The JSB lacks community engagement at any scale. 
Social sustainability in architecture is a broad term. Other meanings, apart from those above, include social coherence, social philosophy, social function, a sense of belonging, social security, social trust, satisfaction of service, social justice, etc. (Habib et al., 2012). Culture is also part of social sustainability, which encompasses areas like context, philosophy, history, function, social norms, custom, values, etc (Kim and Kown, 2018).

The birth and history of the JSB is associated with significant controversy and paradox. The JSB was commissioned by a military dictator, whose primary aim was political rather than to produce an example of worldclass architecture (Choudhury and Bell, 2011). What was meant to be a dictatorial apparatus, after the independence of East Pakistan in 1971, has become a symbol of national pride and prosperity (Choudhury, 2015). In philosophical terms it is socially sustainable, despite its controversial beginning by a questionable client; as it has become the social pride of the people of Bangladesh.

While designing the JSB, Louis Kahn was inspired by Roman ruins and beaux-arts principles of monumental architecture. The form has very little connection to the local context and regional style. Although, according to the existing literature, Kahn was also inspired by the Mahastan garh and Paharpur monastery of Bengal and the surface of JSB complex is a representation of Bengal rural landscape (Choudhury, 2015). However, it is difficult to translate his notion of Bengal in the design of the JSB. Moreover, the JSB cannot be labelled as indigenous or vernacular architecture. Indigenous and vernacular architecture are inherently sustainable and reflect social values and withstand the test of time (Wahid, 2012). Considering the formal, physical and visual aspect, the JSB has not been a significant achievement on the social sustainability scales.

The JSB is a nationalist product. Like nationalism, it represents the dual character of nationalism. On the one hand, it is a symbol of opportunity and emancipation. On the other hand, it is an emblem of oppression and a repository of danger (Choudhury and Armstrong, 2013). For its global stature as architecture it has been acclaimed; however, for its controversial birth it is criticized. It has contributed significantly to the parliamentary affairs of the country, including the formation of the historic constitution of Bangladesh. However, the parliament of the JSB also passed anti-people laws and promoted corrupt politicians. Hence, its sustainability in its broad cultural aspect is shrouded in duality.

\section{JSB AND ECONOMIC SUSTAINABILITY}

The subject of economic sustainability is very critical and controversial in the case of the JSB. The JSB began construction in 1962 when the economy of East Pakistan was in bad shape, despite the contribution of huge amounts of foreign currency from the export of jute and jute products. It was through the construction of the JSB, that Ayub Khan, President of Pakistan, wanted to show that the big brothers of the west are concerned regarding the development of East Pakistan. To him, cost was not a factor, because the main reason for construction was to build something monumental that would please the people of East Pakistan (Choudhury and Armstrong, 2012).

In general, nowadays, economy of sustainability refers to Life Cycle Cost Analysis (LCCA) and the effectiveness of building in monitory terms, which involves the initial cost, building operational costs and recovery costs (Akadiri et al., 2012).

a. Initial cost analysis of JSB: In sustainable terms, initial costs can be saved by using locally sourced materials and using local technology. For the JSB, only the bricks used in the building were locally sourced materials along with masons, labours and craftesmen, i.e., the cement, marble, aluminium, hardwood for the windows and extensive internal panelling, lifts and air-conditioning plant — were all imported (Choudhury, 2015). The technology was also imported and the project Chief Engineer was American engineer, August Eduard Komendant, who was an expert in the field of prestressed concrete. The concept of prestressed concrete was widely used in the JSB.

The design was not modular, and standardized components were not used to achieve cost-effectiveness. Bamboo was the only recycled material used in construction.

b. Building Operation Cost of JSB: The JSB is criticized for its huge maintenance costs, although some minimum maintenance material like concrete and marble was used. Most of the cost was consumed by the electromechanical system used to keep the Indoor Environmental Quality (IEQ) sound and comfortable. At present, due to the rapid economic development of Bangladesh, the maintenance costs do not come to light compared to the time of its commissioning. Vestbro (2002) argued, in exchange for the JSB's operational costs, many social projects like schools, hospitals, housing, and emergency shelters could be built. During the first stage of the operation, 16 lifts of the JSB consumed a disproportional amount of electricity which could otherwise have been provided for lighting a significant portion of the city (Malik, 2000). Because of the huge use of concrete and marble, the weathering effect due to temperature, rain and wind is negligible in JSB. 
c. Recovery Cost: It is expected that the JSB will last many more years to come; probably hundreds of years. It will become an archeological heritage site, once its decay begins, and its recovery value will be priceless.

Akadiri et al. (2012), suggest that economic sustainability should also satisfy the client, user and society. Now let us look at how these three, end-client, user and society, are satisfied, despite the huge cost incurred in building the JSB. Despite its initial cost of about 50 million BDT, Ayub Khan was satisfied with the progress because the structure was able to move and appeal to the people of East Pakistan, especially the elite society. After the independence of Bangladesh, when the independent nation carried out the unfinished work, the cost rose to 1300 million BDT in 1982-1983 (Choudhury, 2015). The devastated, independent nation carried out the work according to the original design because of the JSB's standing as the national pride of Bangladesh. The value of the JSB was more than its monetary cost for the clients, both before and after the independence of Bangladesh.

The users of the JSB are the Members of Parliament from across the country and its support staffs. They feel elated when they assemble for the parliament session inside this iconic building. The indoor ambience which elevates assembly members' pride and value far outweighs its maintenance costs. The JSB's maintenance is run by taxpayers' money. Unfortunately, it remains restricted for the general mass for most of the time. Moreover, rural people who constitute the majority of people in Bangladesh have no understanding of this iconic building. Their mental image cannot comprehend the complexity of this world-renowned, costly building. For the greater peasant and working-class society, it might appear as a costly and meaningless building.

\section{INTROSPECT}

The JSB stands on 610 acres of land and is located at the centre of the growing city of Dhaka. Despite some of its shortcoming in the field of environmental sustainability, it is regarded as the lungs of Dhaka City. So it can be passed on the scale of environmental sustainability. From the perspective of social sustainability, it has a dual standing. It is a symbol of national identity and pride, while again it is disconnected from mass people. From the economic aspect of sustainability, it is controversial. This was reflected in the drama of its receiving the Aga Khan Award for Architecture, which was first suspended in 1986 due to its cost in the context of a poor country (later given in 1989) (Serageldin, Hamedm, 1990). Another factor is that the usable floor space, which is only $41 \%$ of the total built-up area is a concern for cost sustainability issues. Many critics concluded that such an extravagant structure would never have been built, even in developed countries (Choudhury, 2015).

However, Roth states, 'true economy is measured in the quality of performance over the long run, not merely in initial cost' (1998, p. 137). If proper policy is formulated in terms of making it a world heritage site, it will be able to attract many tourists, which will contribute significantly to the country's economy and fame. This type of sustainable, monumental iconic architecture can be a catalyst to bring in economic flow and value for the country, which can be passed on to generation after generation (Yalcinkaya, 2020). Attay and Slik (2019) argue, iconic sustainable buildings have the power to attract globally and can contribute to the national economy by promoting tourism, as it aesthetically, culturally and environmentally exceeds normal standards. Due to the JSB's standing as iconic architecture, its long-term merit could subsidise its cost component and could place Bangladesh with great pride on the global map.

\section{REFERENCES}

Aatty, Hawraa M. S. L., Al Slik Ghada M. R., 2019. Iconic architecture and sustainability as a tool to attract the global attention, Proceedings of 2nd International Conference on Sustainable Engineering Techniques (ICSET), 1-12.

Akadiri Peter, Chinyio Ezekeil, and Olomolaiye Paul, 2012. Design of a Sustainable Building: Conceptual Framework for Implementing Sustainability in the Building Sector, Buildings, 2, 126-152.

Butera, F.M., 2005. Glass architecture: is it sustainable? Proceedings of International Conference 'Passive and Low Energy Cooling for the Built Environment', 161-168.

CELEBi Gulser, 2003. Environmental Discourse and Conceptual Framework for Sustainable Architecture, Environment, 16 (1), 205-216.

Choudhury, B., and Bell G., 2011. The Engagement of Khan and Kahn in Jatio Sangsad Bhaban, Architecture Plus Design, 28(4), 104-111.

Choudhury, B.I., 2015. The Genesis of Jatio Sangsad Bhaban at Shere-Bangla-Nagar [Ph.D Thesis], Department of Architecture, The University of Sydney.

Choudhury, B.I., and Armstrong P., 2012. Monuments and Architecture Shaping Bangladeshi Identity, Global Built Environmental Review, 8(3), 45-67.

Choudhury, B.I., and Armstrong P., 2013. The Duality of Jatio Sangsad Bhaban and the Notion of Nationalism, Journal of Social and Development Sciences, 4(9), 412-424. 
Choudhury, B.I., and Armstrong P., 2013. The Geopolitics of Jatio Sangsad Bhaban in the Cold War Era, Journal of Engineering and Technology, 2(1), 22-28.

Dokumentry Konferencji Narodow Zjednoczonych, 1998. 3-14.06.1992, Warszawa.

Habib Farah, Zabih Hossein I., Mirsaeedie Leila, 2012. Sustainability in Building and Construction: Revising Definitions and Concepts, Int. J. Emerg. Sci., 2(4), 570-578.

Halliday, 2008. Sustainable Construction, London: Butterworth Heinemann.

Kamionka Lucjan, 2011. The Problem of Defining Standards in the Sustainable Architecture Design, Architectus 1(29)., 69-76.

Kim Soomi, and Kwon I Hyun-ah, 2018. Urban Sustainability through Public Architecture, Sustainability, 10, 1249.

Lenzen, M., and Trloar G.J., 2002. Embodied Energy in Buildings: Wood versus Concrete, Energy Policy, 30 , 244-249.

Malik A., 2000. Post-Colonial Capitals of South Asia: A Critical Analysis of Chandigarh, Dhaka and Islamabad, Global Built Environmental Review, 3(1), 68-80.

Roth L.M., 1998. Understanding Architecture, Boulder: West View Press, p.137.

Scoones, Ian, 2007.Sustainability, Development in Practice, 17(4/5), 589-596.

Serageldin I., and Hamedm S., 1990. A Modest and Delightful Balance, Landscape Architecture, 8, 49-51.

Stasinopoulos, Thanos N., 2005. Sustainable Architecture Teaching in Non-Sustainable Societies, The Proceedings of Conference on Passive and Low Energy Architecture, 1-4.

Thormark, C., 2006. The Effect of Material choices on the total energy need and recycling potential of a building, Build, Environ, 41, 1019-1026.

Vestbro, D.U., 2002. Fifteen Years with ARC. PEACE in Architecture as Politics, Vestbro (Ed.), KTH, Sweden. Wahid, Ayesha, 2012. Adapting Vernacular Options for Sustainable Architecture, ISVS e-journal, 2(2), 74-87.

Woodcraft Saffron, Bacon Nicola, Caistor-Arendar Lucia \& Hackett Tricia, Desi Design for Social Sustainability: A framework for creating thriving new communities, University College London, Retrived from https://www.researchgate.net/publication/328581636_Design_for_Social_Sustainability_A_framework for_creating_thriving_new_communities

World Commission on Environment and Development (1987a) Our Common Future: Report of the World Commission on Environment and Development, Oxford: Oxford University Press.

Yalçinkaya Şengül, 2020. Iconic Buildings in Urban Sustainability, Eskişehir Technical University Journal of Science and Technology, 21(2), $282-293$.

(C) 2020 The Authors. Journal of Engineering Science published by Faculty of Civil Engineering, Khulna University of Engineering \& Technology. This is an open access article under the terms of the Creative Commons AttributionNonCommercial-NoDerivatives License, which permits use and distribution in any medium, provided the original work is properly cited, the use is non-commercial and no modifications or adaptations are made. 